\title{
The Use of Fly Ash as Additive Material to High Strength Concrete
}

\author{
Endah Kanti Pangestuti ${ }^{1, a)}$, Sri Handayani 1, b), Mego Purnomo 1, c), \\ Desi Christine Silitonga ${ }^{1}$, M. Hilmy Fathoni ${ }^{1}$ \\ ${ }^{1}$ Departement of Civil Engineering Universitas Negeri Semarang \\ a) Corresponding author: endahkp@mail.unnes.ac.id \\ b) handayani@mail.unnes.ac.id \\ c)nomopur177@gmail.com
}

\begin{abstract}
The use of coal waste (Fly Ash) is currently being developed in building materials technology, as a highstrength concrete mix material. This study aims to determine the strength of concrete by adding fly ash as a substitute for cement in high-strength concrete mixtures. This research was conducted using an experimental method to obtain results and data that would confirm the variables studied. The total numbers of specimens used in this study were 36 pieces with different sizes of cube tests which were $15 \mathrm{~cm} \mathrm{x} 15 \mathrm{~cm} \times 15 \mathrm{~cm}$. A total of 36 concrete samples were used to test the compressive strength of concrete with a percentage of Fly Ash in $0 \%$ (normal concrete), $20 \%$, $25 \%$ and $30 \%$ with a concrete treatment age of 7 days, 21 days and 28 days. A total of 12 more samples were used to test water absorption in concrete at 28 days of maintenance. Each percentage of Fly Ash uses 3 concrete test samples. The increase in compressive strength occurs at 7,21 and 28 days in concrete. However, the compressive strength of concrete produced by concrete using the percentage of Fly Ash is always lower than the value of normal concrete compressive strength. From testing the compressive strength of concrete at 28 days of treatment with content of $0 \%, 20 \%, 25 \%$ and $30 \%$ Fly Ash obtained results of $45.87 \mathrm{MPa}, 42.67 \mathrm{MPa}, 40.89 \mathrm{MPa}$, and $35.27 \mathrm{MPa}$ respectively.
\end{abstract}

Keywords : compressive strength, fly ash, high-strength concrete

\section{INTRODUCTION}

At present, the progress of construction technology in Indonesia is increasing. It is also followed by the development of building materials technology, especially concrete. Nowadays, various types of auxiliary admixtures have been developed and additives for concrete mixtures to improve the performance of concrete into a modern high-performance material that includes strength, durability, service life and efficiency.

In the 1950s, concrete with a compressive strength of $30 \mathrm{MPa}$ was categorized as high-strength concrete. In the 1960 s to the early 1970 s, the criteria were more common to $40 \mathrm{MPa}$. At present, it is called high strength for compressive strength above $50 \mathrm{MPa}$, and $80 \mathrm{MPa}$ as very high strength concrete, while $120 \mathrm{MPa}$ can be categorized as ultra-high strength concrete [1]. High strength concrete according to Indonesian National Standard SNI 03-6468-2000 is concrete which is generally used for pre - stressed concrete such as pre stressed concrete piles, pre - stressed concrete girders, pre - stressed concrete plates and the like with $f^{\prime} c>41$ MPa.

One of the things that influence the strength of concrete is the porosity [2]. The pores in the concrete or porosity is caused because the particles of the concrete constituent material are relatively large, so that the 
density cannot be maximized. The smallest particles of conventional concrete constituent are cement. Reducing cement porosity requires pozzolanic additives and have very fine particles.

One of the additives is fly ash (gray or coal ash), which is produced from Electric Steam Power Plant (PLTU) that uses coal as its fuel. According to ACI [3], fly ash has a fairly fine grain, which is passing No. sieve. 325 (45 milli micron) 5-27\% with specific gravity between 2.16-2.6 and blackish gray. The chemical properties of fly ash in the form of silica and alumina reach $80 \%$. The similarity between the properties of cement makes fly ash a substitute material to reduce the amount of cement as a high-strength concrete constituent material. According to [4], the highest concrete compressive strength was found in concrete mixtures of cement substitution with $10 \%$ Fly Ash at $41.57 \mathrm{MPa}$. Effect of Fly Ash in high quality concrete is the smooth granules of Fly Ash that make concrete more dense because the cavity between the aggregate is filled by Fly Ash, so as to minimize the existing pores and utilize the pozzolanic properties of Fly Ash.

Fly Ash is the result of burning ash in the form of fine and light powder taken from a combustion gas combustion using coal. Fly ash is taken mechanically with an electrostatic precipitation system [5]. Fly ash has a mass density between 2.0-2.5 and a specific area between 170 and 1000 (based on Blaine's air permeability method). While the average particle size of bituminous fly ash is $0.01 \mathrm{~mm}-0.015 \mathrm{~mm}$, its surface area is $1-2$, the density is 2.2-2.4 and the shape of the ball-like particles produces better workability [6]. Fly ash is used as cement substitution for $5 \%-20 \%$ to increase the plasticity of concrete mix and concrete tightness [7]. The use of fly ash $10-15 \%$ as a substitute for cement can increase the strength of concrete [8]. According to SNI S-151990-F [9] fly ash can be classified into three classes of fly ash:

1. Fly Ash Class F, low calcium content, $\mathrm{Ca}<10 \%$ is also called low calcium fly ash which does not have cementitious properties

2. Fly Ash Class $\mathrm{C}$, Class $\mathrm{C}$ fly ash containing $\mathrm{Ca} \geq 10 \%$ has pozolanic properties

3. Fly Ash Class $\mathrm{N}$ is a waste or pozzolan natural volcanic dust which has good pozzolanic properties

Fly Ash from PLTU Tanjung Jati which were tested using X-Ray Fluorescence devices were aluminum $(\mathrm{Al})$ 13\%, Silica ( $\mathrm{Si}$ ) 28.2\%, Lime (Ca) 12.6\%, iron (Fe) 33.8\% [10].nThe study aims to design high quality concrete mixtures with fly ash as cement substitution material with a content of $20 \%, 25 \%$ and $30 \%$ of the weight of cement.

\section{METHODOLOGY}

The materials used in this study were coarse aggregate (gravel) maximum diameter size of $3 \mathrm{~cm}$, fine aggregate (sand) from Muntilan, cement used by Portland type I of the Tigaroda brand, water from the laboratory of Structure and Material of the Faculty of Engineering UNNES, Fly ash comes from PLTU Tanjung Jati Jepara type C, Additive material by Sikamen NN 2\% of the weight of water, shown at Fig 1.

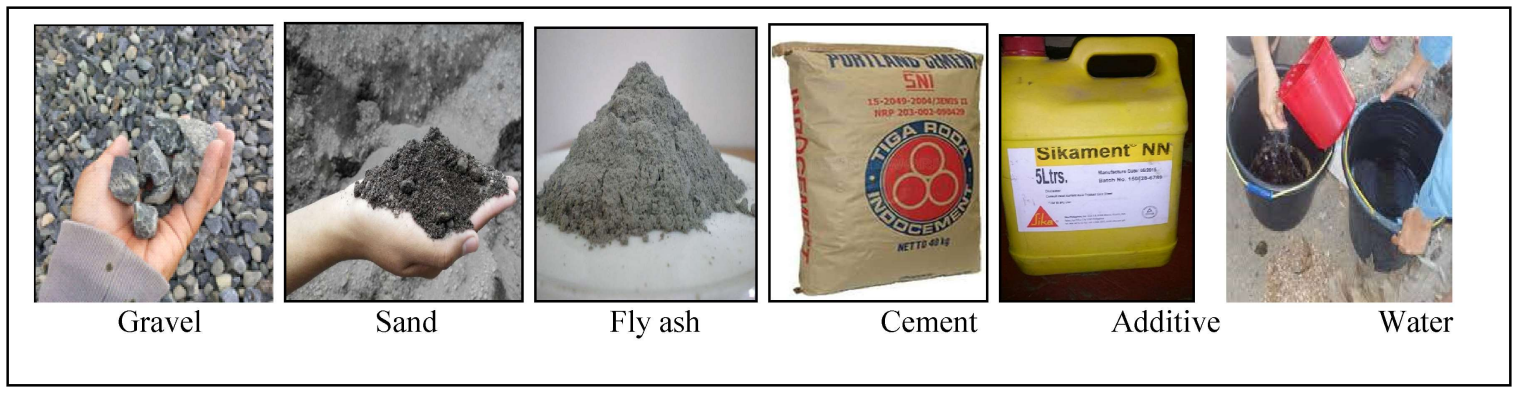

FIGURE 1. Materials used in making concrete

The materials used in the study were coarse aggregate (gravel) with a maximum diameter of $3 \mathrm{~cm}$, fine aggregate (sand) derived from Muntilan area, portlant cement type I with the Tigaroda brand, Water derived from the Structure and Material laboratory of the Engineering Faculty, Universitas Negeri Semarang, Fly ash type C derived from PLTU Tanjung Jati Jepara, additive Sikamen NN 2\% of the weight of the water. The test material used in this study is specimen at the size $15 \times 15 \times 15 \mathrm{~cm}$ as many as 36 pieces. The test specimens were treated with the addition of fly ash as much as $0 \%, 20 \%, 25 \%$, and $30 \%$ for compressive strength testing at the age of 7 days, 21 days and 28 days. Concrete specimen samples are shown at Table 1. Material testing is shown at Figure 2. 
TABLE 1. Number of concrete specimen samples

\begin{tabular}{ccccc}
\hline Fly Ash & $\begin{array}{c}\text { Number of } \\
\text { all Sample } \\
\text { (pieces) }\end{array}$ & \multicolumn{3}{c}{ Number of Sample at age of concrete } \\
\cline { 3 - 5 } & 9 & $\mathbf{7}$ days & $\mathbf{2 1}$ days & $\mathbf{2 8}$ days \\
\hline $\mathbf{0} \%$ & 9 & 3 & 3 & 3 \\
\hline $\mathbf{2 0} \%$ & 3 & 3 & 3 & 3 \\
\hline $\mathbf{3 0} \%$ & 9 & 3 & 3 & 3 \\
\hline
\end{tabular}

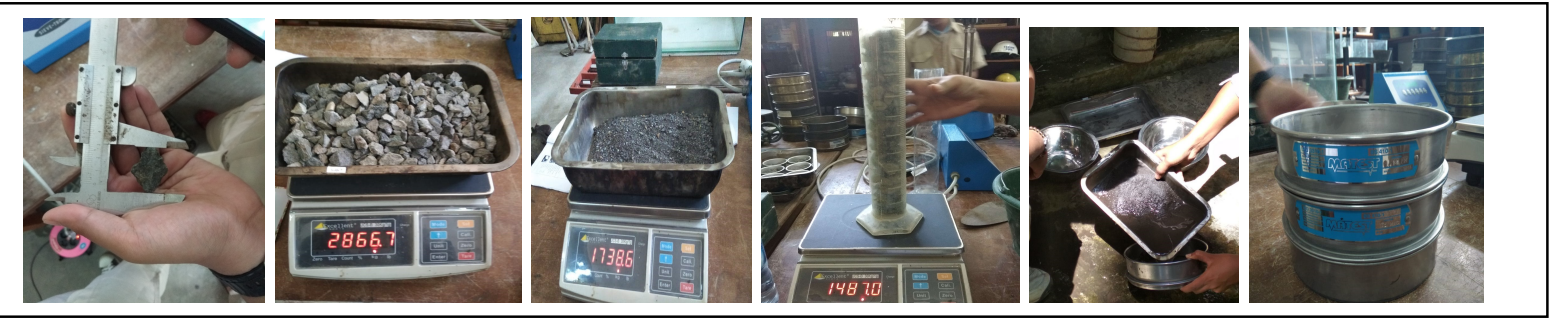

FIGURE 2. Concrete Materials test

The compressive strength of a concrete load is the amount of load per unit area, which causes the concrete test object to be destroyed when loaded with a certain compressive force, which is produced by the press machine [11]. The compressive strength of concrete is obtained from the following formula:

where :

$$
\mathrm{f}^{\prime} \mathrm{c}=\frac{\mathrm{P}}{\mathrm{A}}
$$

f'c = compressive strength of concrete $(\mathrm{kg} / \mathrm{cm} 2)$

$\mathrm{P} \quad=$ maximum load $(\mathrm{kg})$

A $\quad=$ cross section area $\left(\mathrm{cm}^{2}\right)$

\section{RESULTS AND DISCUSSION}

\section{Result of Material Test}

The results of the physical characteristic test of sand and gravel as shown in Table 2.

TABLE 2. The physical characteristic test of sand and gravel

\begin{tabular}{lcc}
\hline \multicolumn{1}{c}{ Testing Name } & Sand & Gravel \\
\hline Finess Modulus & 2,6 & 7,96 \\
\hline Specific Grafity & 2,69 & 2,57 \\
\hline Absortion & $1,71 \%$ & $2,71 \%$ \\
\hline Unit Weight & $1,81 \mathrm{gr} / \mathrm{cm}^{3}$ & $1,33 \mathrm{gr} / \mathrm{cm}^{3}$ \\
\hline Clay Lump & $12,8 \%$ & $1,25 \%$ \\
\hline Los Angeles Test & - & $30,9 \%$ \\
\hline
\end{tabular}

The data which were obtained from the test results of concrete materials were used to design the proportion of concrete mixture. The following mixed planning in accordance with SNI 03-6468-2000 [12] Mix design of concrete is the initial reference for producing high-strength concrete. 
TABLE 3. Composition of Concrete Mixtures per $\mathrm{m}^{3}$

\begin{tabular}{ccccccccc}
\hline No & Fly Ash & $\begin{array}{c}\text { Cement } \\
(\mathbf{k g})\end{array}$ & $\begin{array}{c}\text { Fly Ash } \\
\mathbf{( k g )}\end{array}$ & $\begin{array}{c}\text { Total } \\
\text { Fly ash }+ \text { cement } \\
(\mathbf{k g})\end{array}$ & $\begin{array}{c}\text { Water } \\
(\text { liter) }\end{array}$ & $\begin{array}{c}\text { Sikament } \\
(\mathbf{l i t e r})\end{array}$ & $\begin{array}{c}\text { Sand } \\
(\mathbf{k g})\end{array}$ & $\begin{array}{c}\text { Gravel } \\
(\mathbf{k g})\end{array}$ \\
\hline $\mathbf{1}$ & $\mathbf{0} \%$ & 460,83 & - & 460,83 & 184,33 & 3,686 & 833,30 & 897,30 \\
\hline $\mathbf{2}$ & $20 \%$ & 368,88 & 92,17 & 460,83 & 184,33 & 3,686 & 812,96 & 897,30 \\
\hline $\mathbf{3}$ & $\mathbf{2 5 \%}$ & 345,62 & 115,21 & 460,83 & 184,33 & 3,686 & 807,88 & 897,30 \\
\hline $\mathbf{4}$ & $30 \%$ & 322,58 & 138,25 & 460,83 & 184,33 & 3,686 & 802,79 & 897,30 \\
\hline
\end{tabular}

\section{Slump Test Result}

To find out the workability of the concrete mixture, the slump test was conducted. The test results are shown in Table 4.

TABLE 4. Slump Test Result

\begin{tabular}{ccccc}
\hline Fly Ash & $\mathbf{0 \%}$ & $\mathbf{2 0 \%}$ & $\mathbf{2 5 \%}$ & $\mathbf{3 0 \%}$ \\
\hline Slump (cm) & 6 & 8 & 9 & 12 \\
\hline
\end{tabular}

From the results of the slump test on the table 4, it can be seen that the higher the percentage of use of Fly Ash as cement substitution lead to the higher value of the slump. High slump values produce high workability as well as concrete mix.

\section{Compressive Strength of Concrete}

Compressive strength test was performed to determine the maximum load that can be received by concrete. The testing tool of compressive concrete strength is the UTM (Universal Testing Machine), shown at Figure 5. Testing was carried out at the age of 7 days, 21 days, 28 days with variations of Fly Ash $0 \%, 20 \%, 25 \%$, and $30 \%$. Concrete compressive strength test results can be seen in Table 5

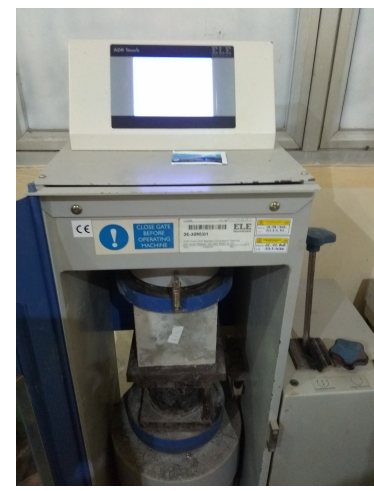

FIGURE 5. Compressive strength test

TABLE 5. Compressive Strength Average of Concrete

(\%)

Compressive Strength Average (MPa)

\begin{tabular}{cccc}
\cline { 2 - 4 } Fly Ash & 7 DAYS & 21 DAYS & 28 DAYS \\
\hline $\mathbf{0}$ & 35,53 & 37,25 & 45,87 \\
\hline $\mathbf{2 0}$ & 36,41 & 37,33 & 42,67 \\
\hline $\mathbf{2 5}$ & 31,63 & 34,51 & 40,89 \\
\hline
\end{tabular}




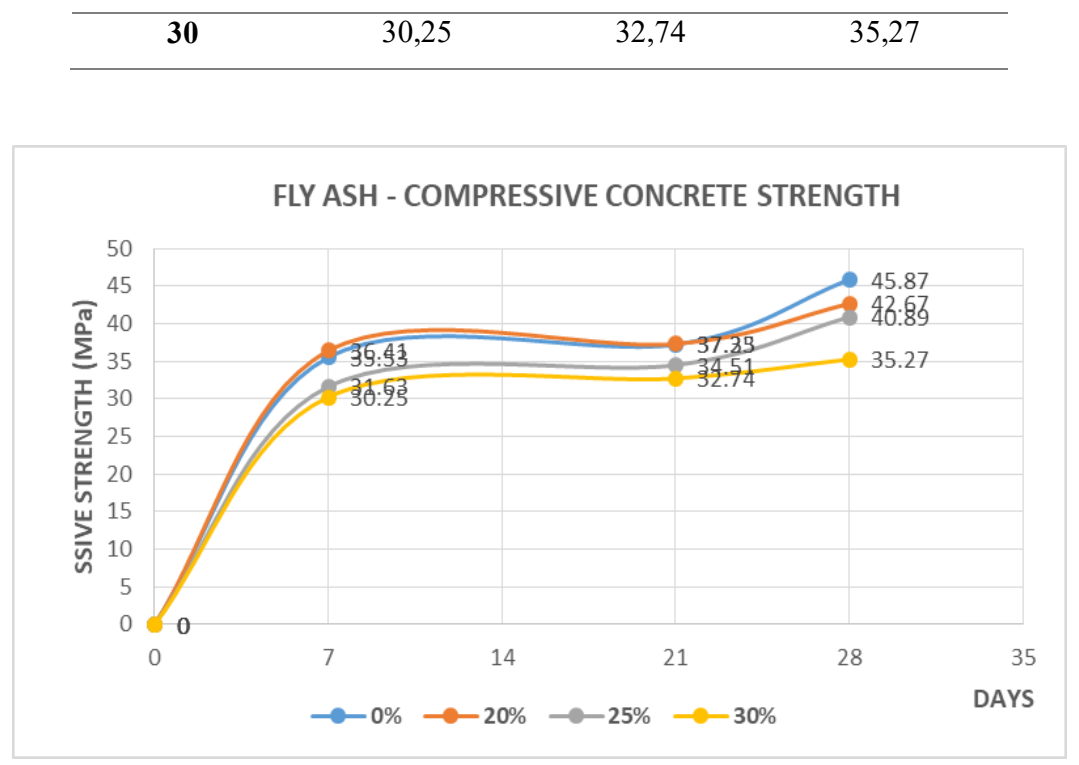

FIGURE 6. The relation of fly ash - compressive concrete strength

The graph at Fig. 6 shows the relationship of the percentage of Fly Ash with the concrete compressive strength produced. The chart has increased from the $7^{\text {th }}$ day to the $28^{\text {th }}$ day of the concrete treatment age. There was an increase in the compressive strength of concrete that used Fly Ash but still below the level of increase in normal concrete 0\% Fly Ash. The percentage of Fly Ash 0\% produced a compressive strength at the maximum condition of $45.87 \mathrm{MPa}$, but the percentage of use of Fly Ash 30\% produced a compressive strength value at a minimum condition of $35.27 \mathrm{MPa}$.

\section{CONCLUSION}

The results of testing the normal compressive strength of $0 \%$ Fly Ash and concrete with cement substitution with Fly Ash 20\%, 25\% and 30\% 28 days of treatment age were 45.87 MPa, 42.67 MPa, 40.89 $\mathrm{MPa}$ and 35.27 $\mathrm{MPa}$ and decreased from normal concrete $6.97 \%, 10.85 \%$, to $23.10 \%$. From these results, it can be seen that the greater the percentage of use of Fly Ash as a substitute for cement, the compressive strength decreases. Concrete with the use of $20 \%$ Fly Ash produces a compressive strength that is better than the content of Fly Ash $25 \%$ and Fly Ash $30 \%$. This is supported by the opinion of Ratmaya said that the best use of Fly Ash as an additive is $20 \%-30 \%$. Excessive use of 30\% Fly Ash causes not all waste of Fly Ash to react with water and cement in a concrete mixture. Fly Ash which cannot react causes the binding strength of the concrete mixture to decrease and the result is the strength of the concrete decreases [13].

\section{REFERENCES}

[1] F.X. Supartono, Mengenal dan Mengetahui Permasalahan pada Produksi Beton Berkinerja Tinggi, artikel ilmiah, UI, Jakarta 1998.

[2] Kardiono Tjokrodimuljo, Teknologi Beton. Yogyakarta: Biro Penerbit KMTS FT UGM, 2007.

[3] American Concrete Institute, ACI Manual of Concrete Practice 1999 Part 1 : Material and General Properties of Concrete , ACI International. Farmington Hill.1999.

[4] Mardiono. "Effect of The Use of Fly Ash Concrete in High Quality", Jurnal Ilmiah Desain dan Konstruksi Vol 9, No 1 (2010). Universitas Gunadarma Jakarta, 2010.

[5] S.Y. Hidayat, "Penelitian Pendahuluan Pemanfaatan Abu Terbang (Fly Ash) untuk Campuran Beton di Indonesia", Jakarta: Jurnal Litbang Vol. III No. 4-5 April and May, 1986.

[6] Antoni and P. Nugraha, Teknologi Beton. , C.V Andi Offset, Yogyakarta. 2007.

[7] Ridwan Suhud, "Beton Mutu Tinggi". Jurnal Penelitian Pemukiman Vol. 14 No. 7-8 July - August, 1993 
[8] Surya Sebayang, "Pengaruh Kadar Abu Terbang Terhadap Kuat Tekan Beton alir Mutu Tinggi", Jurnal Penelitian Rekayasa Sipil dan Perencanaan, Edisi VI, 2002.

[9] Standar Nasional Indonesia (SNI), Tata Cara Perencanaan Campuran Tinggi Dengan Semen Portland Dengan Abu terbang, SNI 03-6468-2000, Badan Standardisasi Nasional, 2000.

[10] Erwin Rommel, Dini Kurniawati and Arman Putra. "Improvement of the Physical Properties and Reactivity of Fly Ash as Cementitious on Concrete". Jurnal Media Teknik Sipil, No.12, Vol. 2, pp. 111-118, Agustus 2014

[11] Standar Nasional Indonesia (SNI), Metode Pengujian Kuat Tekan Beton, ICS 91.100.3, Badan Standarisasi Nasional, 1990

[12] Standar Nasional Indonesia (SNI). Tata Cara Perencanaan Campuran Tinggi Dengan Semen Portland Dengan Abu terbang. SNI 03-6468-2000. Badan Standardisasi Nasional. 2000.

[13] Urip Ratmaya, Teknologi Semen dan Beton: Fly Ash, Mengapa Seharusnya Dipakai pada Beton. Gresik: PT. Semen Gresik Indonesia dan PT. Varia Usaha Beton . 2003 